\title{
Nanotization, Characterization and In-Vitro Activity of Kushta-E-Qalai (Tin Calx): A Traditional Unani Medicine of India
}

\author{
Syed Mohammad Umair ${ }^{1}$, Sumbul Rehman', Tajuddin², Siddiqi KS ${ }^{3}$ and Shahab AA Nami* \\ ${ }^{1}$ Department of Ilmul Advia, Faculty of Unani Medicine, Aligarh Muslim University, Aligarh 202002, India \\ ${ }^{2}$ Department of Saidla, Faculty of Unani Medicine, Aligarh Muslim University, Aligarh 202002, India \\ ${ }^{3}$ Department of Chemistry, Aligarh Muslim University, Aligarh 202002, India \\ ${ }^{4}$ Department of Kulliyat, Faculty of Unani Medicine, Aligarh Muslim University, Aligarh 202002, India
}

\begin{abstract}
The present study reports a novel method of preparation of kushta-e-qalai, a well-known Indian traditional drug of Unani system of medicine prepared from stannum. In this work the Tin calx (kushta-e-qalai) was prepared by laboratory method in order to develop a standard protocol both in terms of synthesis and its subsequent conversion to nanoscale termed as nanotization. The finished kushta-e-qalai was characterized using standard analytical techniques like Scanning Electron Microscopy (SEM), Transmission Electron Microscopy (TEM) and X-Ray Diffraction (XRD). It was inferred that the kushta-e-qalai contains nano-particles of tin-oxide in the range of 20 to $40 \mathrm{~nm}$. During the TLC examination of kushta-e-qalai a single spot was observed in a variety of solvents implying the complete conversion of stannum into its calx. The kushta-e-qalai was screened for its possible biological activity. The results obtained are indicative that the kushta-e-qalai possesses significant anti-bacterial activity against Streptococcus mutans and Corynebacterium xerosis. The $\mathrm{LD}_{50}$ of kushta-e-qalai was also analyzed by the graphical method of Miller and Tainter and was found to be $1250 \mathrm{mg} / \mathrm{kg}$ b.w.
\end{abstract}

Keywords: Kushta-e-Qalai; Unani system; Nanotization, Antimicrobial activity; Streptococcus mutans

\section{Introduction}

From time immemorial, a variety of metals and minerals are effectively used to cure various ailments. Probably the Roman physician, Pliny and Greek philosopher, Dioscrides were the first to use gold in medicine while Hippocrates, explained the beneficial healing and antidisease properties of silver [1]. Islamic philosophers notably Jehane Ragai [2] made great contributions to pharmacy and alchemy and probably the art of calcination is mainly derived from the alchemical techniques used during the Arabian era of Unani medicine [3]. They described several alchemical procedures including calcination of metals and minerals and also classified those into six divisions, placing tin in second group namely Al-Ajsad or seven bodies [4]. One of the famous philosopher of all times Abu Bakr Mohammad Bin Zakaria Razi generally known as Rhazes described a comprehensive list of apparatus employed in alchemy in general and calcination in particular [5]. Razi coined the term taklees for calcination. Chemically, kushta may be defined as the calcined product of any desired metal or mineral while literally kushta means "to kill" [1]. In medical terms, it is defined as the detoxification of the harmful properties of a metal. The calcined forms of metals are termed bhasmas, parpams and kushta in Ayurveda, Siddha and Unani system of medicine, respectively [6]. The kushta made from the calcination of purified Qalai or Tin is called as kushta-e-qalai [7]. In Unani system of medicine kushta-e-qalai is used to treat various diseases like spermatorrhoea, excessive nocturnal emission, premature ejaculation and Syphilis [8] but not in infectious disorders caused by bacteria. Kushta has been considered as one of the most efficacious class of drugs used in Unani system. It is quite popular in traditional system of medicine practiced in rural as well as urban India [9]. The normal prescribed dose of most of the kushta is about one grain of rice which is equivalent to about $1 \mathrm{mg}$. The high efficacy of kushta may be due to its very small particle size which has high propensity of absorption [10]. Although, kushta of various metals and minerals are in use for decades but to the best of our knowledge no scientific parameters or standard scientific protocols have been developed for the preparation and characterization of these age old remedies [11]. A brief survey of classical texts reports very crude methodologies of preparation and authentication of kushta. From the clinical point of view these kushta are used in a variety of ailments even today. For instance, kushta of gold or kushta-e-tila is used in the treatment of variety of cancers [12] specifically in rheumatoid arthritis [13]. Similarly, kushta of tin more commonly called as kushta-e-qalai is effectively used in the treatment of premature ejaculation, diabetes, spermatorrhoea, etc. [14]. From these enticing findings we find it worth to establish standard protocols for the preparation and characterization of kushta-e-qalai. Moreover, we have also explored the in-vitro antibacterial activity of kushta-eqalai against six gram positive and four gram negative bacteria. The minimum inhibitory concentration (MIC) and minimum bactericidal concentration (MBC) have also been calculated.

\section{Material and Methods}

\section{General consideration}

All the chemicals and metals including tin granules used in this study were of A.R. Grade and procured from Merck and Ranbaxy, India Ltd. Alum was procured from herbs and drug store of central pharmacy of the Ajmal Khan Tibbiya College, AMU, Aligarh. Leaves of Cannabis sativa and Aloe berbadensis plants were collected from the herbal garden of Department of Ilmul Advia, Faculty of Unani Medicine, AMU, Aligarh.

*Corresponding author: Shahab AA Nami, Department of Kulliyat, Faculty of Unan Medicine, Aligarh Muslim University, Aligarh 202002, India, Tel: 08439097792; E-mail: saanami.tc@amu.ac.in

Received June 15, 2015; Accepted July 02, 2015; Published July 04, 2015

Citation: Umair SM, RehmanS, Tajuddin, SiddiqiKS, Nami SAA(2015)Nanotization, Characterization and In-Vitro Activity of Kushta-E-Qalai (Tin Calx): A Traditional Unani Medicine of India. Pharm Anal Acta 6: 388. doi:10.4172/21532435.1000388

Copyright: $\odot 2015$ Umair SM, et al. This is an open-access article distributed under the terms of the Creative Commons Attribution License, which permits unrestricted use, distribution, and reproduction in any medium, provided the original author and source are credited. 
In order to standardize the drug in terms of particle size, particle morphology, composition, heavy metal content as well as chemical nature, standard analytical tests like Scanning Electron Microscopy (SEM) Jeol, Model JSM6100, EDAX, Transmission Electron Microscopy (TEM), Hitachi, H-7500, X-ray Diffractometer-Powder method (XRD) of kushta-e-qalai were done. However, the physicochemical tests like gravimetric analysis, $\mathrm{HCl}$ digestion were done in accordance with the reported methods [15]. Whilst traditional tests were also carried out to standardize the final drug in accordance with classical parameters given in official pharmacopeias like finger thumb test to check fineness (size), still water test to check density and luster test to check metallic shine (chemical nature) of the traditional kushta-e-qalai.

\section{Preparation of Kushta-E-Qalai}

Kushta-e-qalai prepared from modern methodology, involves the latest tools and instruments like digital muffle furnace, ball mill mixer, digital tungsten pyrometer etc., instead of using traditional tools and instruments like pit furnace, cow dung cakes for ignition etc. Methodology: $12 \mathrm{~g}$ of alum was heated to its melting point until it becomes white. It was cooled and grinded to obtain micro fine powder. Then $50 \mathrm{~g}$ of tin granules were also heated and stirred occasionally to its melting point. The alum powder obtained above was sprinkled in small aliquots over the melted tin over a period of 1 hour. The stirring was continued until all the sprinkled alum gets disappeared. The mixture was cooled and the calcined tin was grinded in a black agate stone mortar and pestle with $20 \mathrm{~mL}$ of Aloe water (sap of plant Aloe barbadeniss) until it becomes dry enough to be grinded into micro fine powder to obtain raw herbo-metallic kushta-e-qalai. This was grinded thrice and filtered through sieve no. 300 to obtain the final kushta-eqalai.

\section{Conversion of micro fine Kushta-E-Qalai into nanoparticulate form}

For the conversion of micro fine herbo-metallic kushta-e-qalai, vigorous and continuous grinding was done in an automatic time controlled mortar and pestle. It was grounded for several hours for three days to obtain the nanofine kushta-e-qalai.

\section{Test microorganisms and medium}

Ten bacterial strains, six gram positive; Staphylococcus aureus ( $\mathrm{Sa}$ ), Streptococcus mutans (Sm), Streptococcus pyrogenes (Sp), Staphylococcus epidermidis (Se), Bacillus cereus (Bc) and Corynebacterium xerosis $(C x)$ while four gram negative Pseudomonas aeruginosa $(\mathrm{Pa})$, Proteus vulgaris $(P v)$, Klebsiella pneumonia (Kp) and Escherichia coli $(E c)$ were selected on the basis of their clinical importance in causing diseases in humans. These were obtained from HiMedia Labs Pvt. Ltd., Mumbai, India and Microbial Type Culture Collection, Chandigarh, Punjab, India. The standard strains selected for the study were Staphylococcus aureus (ATCC 29213), Streptococcus mutans (ATCC 25175), Streptococcus pyrogenes (MTCC 435), Staphylococcus epidermidis (MTCC 435), Bacillus cereus (MTCC 430), Corynebacterium xerosis (ATCC 373), Escherichia coli (ATCC 25922), Klebsiella pneuomoniae (MTCC 109), Proteus vulgaris (MTCC 426) and Pseudomonas aeruginosa (MTCC 424). The solid media namely Nutrient Agar No.2 (NA) (M 1269S-500G, HiMedia Labs Pvt. Ltd., Bombay, India) was used for preparing nutrient plates, while Nutrient Broth (NB) (M002-500G, HiMedia Labs Pvt. Ltd., Bombay, India) was used for the liquid culture media.

\section{In-Vitro antibacterial activity}

Primary screening: The antibacterial activity of the kushta-e- qalai was evaluated by agar well diffusion method. All the microbial cultures were adjusted to $0.5 \mathrm{McF}$ arland standards, which was visually comparable to a microbial suspension of approximately $1.5 \times 10^{8} \mathrm{cfu} / \mathrm{ml}$. $20 \mathrm{ml}$ of agar media was poured into each petri plate and the plates were swabbed with a colony from the inoculums of the test microorganisms and kept for $15 \mathrm{~min}$ for adsorption. Using sterile cork borer of $6 \mathrm{~mm}$ diameter, wells were bored into the seeded agar plates and these were loaded with a $50 \mu \mathrm{l}$ volume with concentration of $10 \mathrm{mg} / \mathrm{ml}$ of each compound reconstituted in the dimethylsulfoxide (DMSO). All the plates were incubated at $37^{\circ} \mathrm{C}$ for $24 \mathrm{~h}$.

Antimicrobial activity of all the kushta-e-qalai was evaluated by measuring the zone of growth inhibition against the test microorganisms with Antibiotic Zone Scale (PW297, HiMedia Labs Pvt. Ltd., Mumbai, India), which was hold over the back of the inverted plate. The plate was held a few inches above a black, nonreflecting background and illuminated with reflected light. The medium with DMSO as solvent was used as a negative control whereas media with Ciprofloxacin (standard antibiotic for gram positive) and Gentamicin (standard antibiotic for gram negative) were used as positive control. The experiments were performed in triplicate.

\section{Determination of minimum inhibitory concentration (MIC) and minimum bactericidal concentration (MBC) of Kushta- E-Qalai}

Minimum inhibitory concentration (MIC) is the lowest concentration of an antimicrobial compound that will inhibit the visible growth of microorganisms after overnight incubation. Minimum inhibitory concentrations are important in diagnostic laboratories to confirm resistance of microorganisms to antimicrobial agents and also to monitor the activity of new antimicrobial agents. The MIC of the kushta-e-qalai was tested against bacterial strains through broth dilution method. In this method, the test concentrations of kushta-eqalai were made from 2.5 to $0.01 \mathrm{mg} / \mathrm{ml}$ in the sterile wells of the microtiter plates.

\section{Broth dilution method}

In a sterile microtitre plates (96-u-shaped wells) $50 \mu \mathrm{l}$ of the sterile nutrient broth was poured in each well in three rows, than from a fresh inoculums so formed $\left(10^{8} \mathrm{cfu} / \mathrm{ml}\right.$ diluted with $100 \mu \mathrm{l}$ Nutrient broth to have $10^{6} \mathrm{cfu} / \mathrm{ml}$ ). $50 \mu \mathrm{l}$ of the suspension was poured in each well in the first and third row, second row was again filled with $50 \mu \mathrm{l}$ of Nutrient broth, finally the kushta-e-qalai $50 \mu \mathrm{l}$ was added in the first row diluting uniformly from 2.5 to $0.01 \mathrm{mg} / \mathrm{ml}$ till the $8^{\text {th }}$ well. MIC was expressed as the lowest dilution, which inhibited the growth judged by lack of turbidity in the well.

\section{Results and Discussion}

The kushta-e-qalai incorporating the tin metal in nanoparticulate form as the main ingredient is a calcined form of Stannum (tin metal). Chemically kushta-e-qalai is stannous metal and its oxide (or Tin) as confirmed by atomic absorption spectroscopy (AAS) and EDAX. At pH $>6$, stannous compounds are easily oxidized. Stannous compounds are more readily absorbed in the gastrointestinal tract than their stannic counterparts [16]. The main objective of the study is the preparation of kushta-e-qalai according to traditional method of processing and modern method of calcinations. Moreover, the assessment of particle size as well as composition of the kushta-e-qalai and in-vitro antibacterial activity on wide spectrum of gram positive as well gram negative strains of bacteria has also been carried out. The TEM and 
Citation: Umair SM, Rehman S, Tajuddin, Siddiqi KS, Nami SAA (2015) Nanotization, Characterization and In-Vitro Activity of Kushta-E-Qalai (Tin Calx): A Traditional Unani Medicine of India. Pharm Anal Acta 6: 388. doi:10.4172/21532435.1000388

XRD reveals nanoparticulate nature of the kushta-e-qalai having the mixture of solid metal and metal oxide particles agglomerated with some organic compounds in the range of 5-15 nm. While the results of in-vitro activity of the drug have shown significant activity against three gram positive strains viz. Staphylococcus aureus, Corynebacterium xerosis, Bacillus aureus and one gram negative strain Klebsiella pneumoniae. Moderate activity was observed against two gram positive bacteria Streptococcus pyogenes, Streptococcus mutans and two gram negative bacteria Pseudomonas aeruginosa and Proteus vulgaris. The zone of inhibition as well as activity index (AI) against two gram positive strains namely Streptococcus mutans and Corynebacterium xerosis was found to be 11, $16 \mathrm{~mm}$ and 100,123\%, respectively (Table 1-3).

The particle size of kushta-e-qalai as inferred from TEM were found to be in the range $31-36 \mathrm{~nm}$ (Figure 1) while the metal contents determined by energy dispersive X-ray analysis (EDAX) showed primarily tin and other constituents present in the sample (Figure 2). Some other elements have also been detected in trace amounts which are given below in the tabular and graphical form. The powder XRD patterns of the kushta-e-qalai are shown in Figure 3. The XRD pattern of both kushta indicates that it is a mixture of tin metal and hexagonal

\begin{tabular}{|c|c|c|c|c|}
\hline \multirow[b]{2}{*}{ S. No. } & \multirow[b]{2}{*}{ Strain } & \multicolumn{2}{|c|}{ Zone of Inhibition (in mm) } & \multirow[b]{2}{*}{$\mathrm{MIC}(\mathrm{mg} / \mathrm{ml})$} \\
\hline & & $\begin{array}{l}\text { kushta-e-qalai } \\
\text { (40 } \mu \mathrm{l} / \text { well })\end{array}$ & $\begin{array}{l}\text { Standard } \\
(30 \mu \mathrm{g} / \mathrm{disk})\end{array}$ & \\
\hline 1. & S. aureus (Sa) & 7 & 28 & $>2.5$ \\
\hline 2. & S. mutans (Sm) & 13 & 30 & 1.25 \\
\hline 3. & S. epidermidis (Se) & 11 & 28 & $>2.5$ \\
\hline 4. & S. pyrogenes (Sp) & 7 & 30 & $>2.5$ \\
\hline 5. & B. cereus $(\mathrm{Bc})$ & 7 & 30 & $>2.5$ \\
\hline 6. & C. xerosis (Cx) & 7 & 28 & $>2.5$ \\
\hline 7. & E. coli (Ec) & 7 & 27 & $>2.5$ \\
\hline 8. & K. pneuomoniae (Kp) & 7 & 27 & $>2.5$ \\
\hline 9. & P. aeruginosa $(\mathrm{Pa})$ & 7 & 28 & $>2.5$ \\
\hline 10. & P. vulgaris $(\mathrm{Pv})$ & 7 & 30 & $>2.5$ \\
\hline
\end{tabular}

Remark: MIC of kushta-e-qalai given for S. mutans was found to be $0.312 \mathrm{mg} / \mathrm{ml}$ Table 1: Antibacterial screening of kushta-e-qalai against gram positive strains.

\begin{tabular}{|c|c|c|c|c|c|c|c|c|c|c|}
\hline \multirow{2}{*}{ Sample } & \multirow{2}{*}{$\begin{array}{c}\text { Concentration } \\
(\mathrm{mcg} / \mathrm{ml})\end{array}$} & \multicolumn{9}{|c|}{$\begin{array}{l}\text { Inhibition zone } \\
\quad(\mathrm{mm})\end{array}$} \\
\hline & & $\mathrm{Sa}$ & Sp & Sm & Cx & $\mathrm{Bc}$ & Ec & $\mathrm{Kp}$ & $\mathrm{Pa}$ & $\mathrm{Pv}$ \\
\hline \multirow{3}{*}{ kushta-e-qalai } & 5 & 6 & 0 & 0 & 3 & 0 & 3 & 5 & 0 & 0 \\
\hline & 25 & 14 & 8 & 6 & 6 & 5 & 7 & 11 & 5 & 8 \\
\hline & 50 & 20 & 11 & 11 & 16 & 17 & 0 & 21 & 11 & 11 \\
\hline $\begin{array}{l}\text { Standard-I } \\
\text { (For G + ive } \\
\text { Strains) } \\
\text { Ciprofloxacin }\end{array}$ & 30 & 32 & 15 & 11 & 13 & 31 & --- & --- & --- & --- \\
\hline $\begin{array}{l}\text { Standard-II } \\
\text { (For G -ive } \\
\text { Strains) } \\
\text { Gentamycin }\end{array}$ & 30 & --- & --- & --- & -- & --- & 28 & 30 & 34 & 18 \\
\hline
\end{tabular}

Table 2: In vitro antibacterial activity of Powder XRD studies kushta-e-qalai in terms of concentration and Zone of inhibition.

\begin{tabular}{|c|c|c|c|c|c|c|c|c|c|c|}
\hline \multirow{2}{*}{$\begin{array}{l}\text { Kushta- } \\
\text { e-qalai }\end{array}$} & \multirow{2}{*}{$\begin{array}{c}\text { Concentration } \\
(\mathrm{mcg} / \mathrm{ml})\end{array}$} & \multicolumn{9}{|c|}{ Activity index (A.I.) } \\
\hline & & Sa & $S p$ & $\mathrm{Sm}$ & $C x$ & $\mathrm{Bc}$ & Ec & $\mathrm{Kp}$ & $\mathrm{Pa}$ & $\mathrm{Pv}$ \\
\hline -do- & 5 & 0.18 & 0 & 0 & 0.23 & 0 & 0.10 & 0.16 & 0 & 0 \\
\hline -do- & 25 & 0.43 & 0.53 & 0.54 & 0.46 & 0.16 & 0.25 & 0.36 & 0.14 & 0.44 \\
\hline -do- & 50 & 0.62 & 0.73 & 1.0 & 1.23 & 0.54 & 0 & 0.70 & 0.32 & 0.61 \\
\hline
\end{tabular}

Table 3: In-vitro antibacterial activity of Powder XRD studies kushta-e-qalai in terms of concentration and activity index.

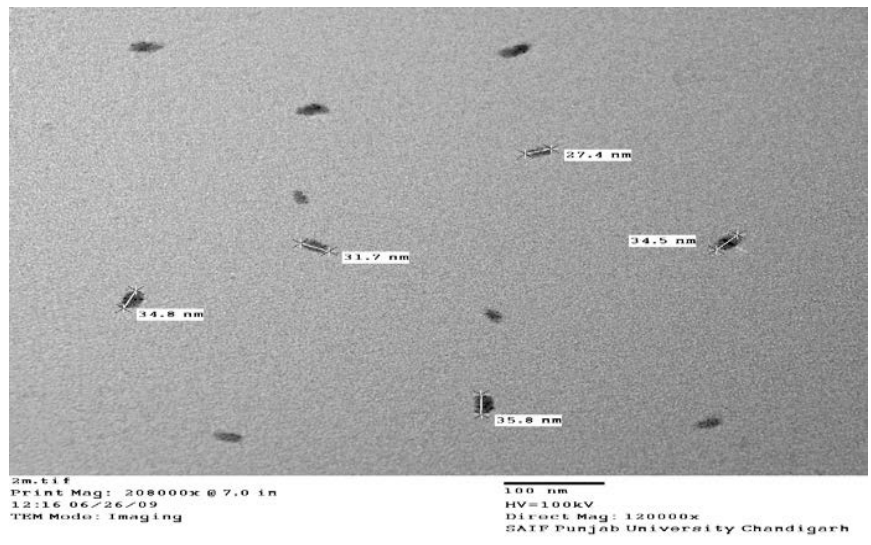

Figure 1: TEM micrograph of kushta-e-qalai.

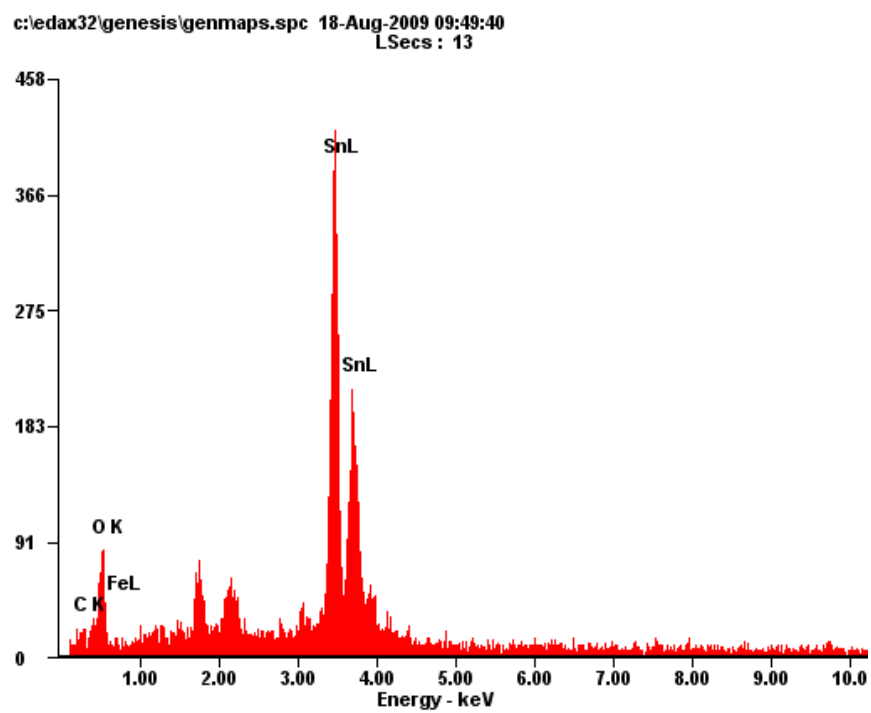

Figure 2: EDAX pattern of kushta-e-qalai.

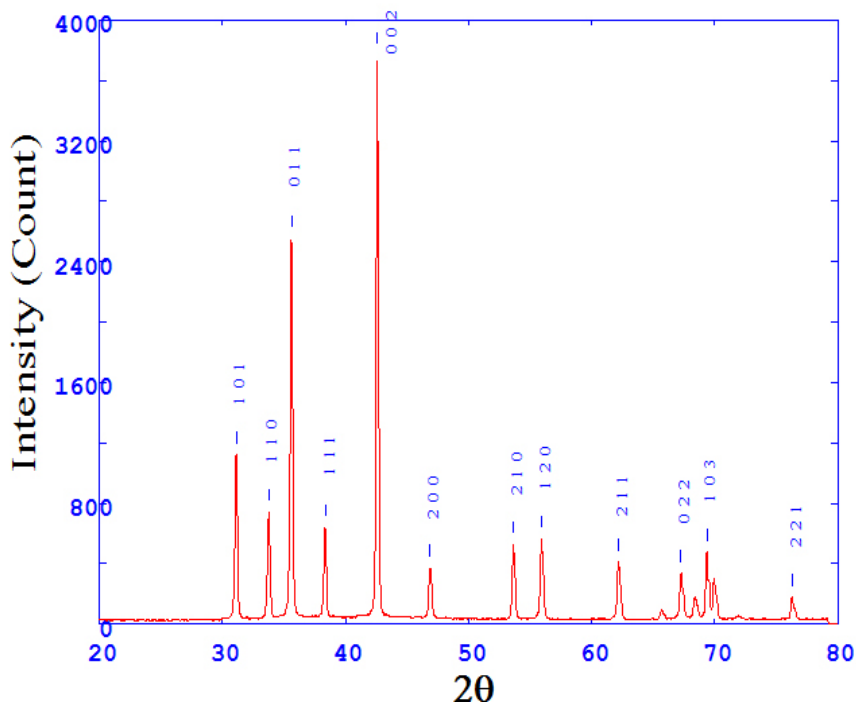

Figure 3: Powder XRD patterns of kushta-e-qalai. 
Citation: Umair SM, Rehman S, Tajuddin, Siddiqi KS, Nami SAA (2015) Nanotization, Characterization and In-Vitro Activity of Kushta-E-Qalai (Tin Calx): A Traditional Unani Medicine of India. Pharm Anal Acta 6: 388. doi:10.4172/21532435.1000388

Page 4 of 4

tin oxide implying that the metal was partly converted into its oxide. However, the major change was observed in the physiological form of the sample. The powder XRD pattern of the sample shows the presence of twelve peaks at $\mathrm{d}=2.87178,2.65252,2.51932,2.34535,2.12196$, $1.93616,1.70718,1.64268,1.49154,1.39063,1.35382,1.24706 \AA$, respectively. The XRD pattern of kushta-e-qalai exclusively matches with tetragonal tin oxide (JCPDS no. 77-0456). The crystallite size was determined using the Scherrer equation and were found to be 40.57 $\mathrm{nm}$.

\section{Physico-Chemical Tests}

A. Raw material

\begin{tabular}{|l|l|l|}
\hline Raw material & Density $(\mathrm{g} / \mathrm{ml})$ & Gravimetric Estimation (\% of metal)
\end{tabular}

Tin powder (Merck) $5.769 \mathrm{~g} / \mathrm{cm}^{3}$

B. Organoleptic features

\begin{tabular}{|l|l|l|}
\hline \multicolumn{2}{|l|}{ kushta-e-qalai } \\
\hline Features & Actual & Expected (as given in classical Unani texts) \\
\hline Color & Greyish-white & Muddy \\
\hline Appearance & Fine powder & Same \\
\hline Taste & Tasteless & Same \\
\hline
\end{tabular}

C. Physical test

\begin{tabular}{|l|l|l|l|}
\hline kushta-e-qalai & Metallic luster & Finger-thumb test & Still water test \\
\hline Results & - & + & + \\
\hline
\end{tabular}

D. Physical properties

\begin{tabular}{|l|l|l|l|l|l|}
\hline $\begin{array}{l}\text { Kushta } \\
\text { (Calx) }\end{array}$ & $\mathrm{pH}$ & Appearance & Solubility & $\begin{array}{l}\text { Gravimetric } \\
\text { metal content \% } \\
\text { (Conventional) }\end{array}$ & $\begin{array}{l}\text { Gravimetric } \\
\text { metal content } \\
\% \text { (Modern) }\end{array}$ \\
\hline Qalai & 6.95 & Powder & $\begin{array}{l}\text { In water gives } \\
\text { a faint color }\end{array}$ & 85.1 & 82.4 \\
\hline
\end{tabular}

\section{Conclusion}

Kushta-e-qalai in its nanoparticulate form exhibited strong bactericidal activity against majority of gram positive strains and few of gram negative strains. Highest bactericidal activity was observed against Streptococcus mutans and Corynebacterium xerosis. Association of Streptococcus mutans with dental caries is highly evident. It may be proposed that kushta-e-qalai can be used in dental powders, dental implants having tin as one of the contents, in amalgams, as well as chewable or dispersible antibacterial tablets, dusting powder or ointments in C. xerosis infections. The study demonstrated that kushtae-qalai possess significant antimicrobial activity against Streptococcus mutans and Corynebacterium xerosis. However, there is an urgent need for further research on this invaluable traditional drug regarding its standardization, dose toxicity and efficacy with respect to human cells.

\section{References}

1. Sudha A, Murty VS, Chandra TS (2009) Standardization of Metal-Based Herbal Medicines. American Journal of Infectious Diseases 5: 200-206.

2. Ragai J (1992) The Philosopher's Stone: Alchemy and Chemistry. Alif Journal of Comparative Poetics 12: 58-77.

3. Holmyard EJ (1924) Maslama al=Majriti and the Rutbatu'l=Hakim. Isis 6: 293305.

4. Anawati GC (1996) The Encyclopedia of the History of Arabic Science 3: 853902.

5. Clagett M (1961) The Science of Mechanics in the Middle Ages. University of Wisconsin Press, US.

6. Mishra LC (2003) Scientific Basis for Ayurvedic Therapies. CRC Press, US: 86.

7. National Formulary of Unani Medicine, Central Council of Research in Unani Medicine: 66.

8. Said M (1970) Hamdard Pharmacopoeia of Eastern Medicine, Second impression. Hamdard Academy, Krachi: 232-234.

9. Burckhardt T (1997) Alchemy: Science of the Cosmos, Science of the Soul Stuart and Watkins, US: 29.

10. Brown CL, Bushell G, Whitehouse MW, Agrawal DS, Tupe SG, et al. (2007) Gold Bulletin 40: 250.

11. Cardarelli NF (1986) Tin as a vital nutrient: implications in cancer prophylaxis and other physiological processes. CRC Press, Florida.

12. Boulanger D (2002) The Islamic Contribution to Science, Mathematics and Technology: Towards Motivating the Muslim Child, OISE Papers in STSE Education 3.

13. Kapoor RC (2010) Some observations on the metal-based preparations in the Indian system of medicine. Indian Journal of Traditional Knowledge 9: 562-575.

14. El-Eswed, Bassam I (2002) Lead and Tin in Arabic Alchemy. (Arabic Sciences and Philosophy) Cambridge University Press, US: 139-153.

15. Vogel Al (1986) Determination of chloride as silver chloride. Quantitative Inorganic Analysis, Longman Green and Co., London: 405.

16. WHO (1980) Tin and organotin compounds: a preliminary review. (Environ Health Crit) World Health Organization: 15-109. 